\title{
PEMBERDAYAAN PELADANG BERPINDAH: KASUS KABUPATEN KUTAI KARTANEGARA, KABUPATEN KUTAI TIMUR, DAN KABUPATEN KUTAI BARAT DI PROVINSI KALIMANTAN TIMUR
}

\author{
Jawatir Pardosi, Pang S. Asngari, Rudy C. Tarumingkeng, \\ Djoko Susanto, dan Sumarjo
}

\begin{abstract}
Shifting cultivations (SC) who rely on their livelihood of forest resources are empowerless mainly caused by the low quality of human resources an the pressures of the forest resources utilization which covering the cultivation areas by companies. The study was aimed to formulate a model of the empowerment of SC through extension program. The respondents involved we composed of 36 extension agents and 288 shifting cultivators. Data analysis used the descriptive analysis technique such as Chi Square, Rank Spearman, and Path Analysis. The Study results showed ah: (1) factors related o empowering SC through extension that consisted of 13 variables were low; (2) applications of forestry extension in Kutai Katanegara District, East Kutai District, and West Kutai District were not able to empower the SC to realize sustainable forest; (3) the activities needed by SC are he activities, aimed to solved the SC problem, such as (a) he qualified extension about the permanent cultivation, $(b)$ the availability of infrastructure, $(c)$ the insurance for shifting cultivation activities, (d) the availability of specific local technology, (e) production apparatus, $(f)$ production increase, $(g)$ income increase, $(h)$ market, $(i)$ cooperation, $(j)$ capital credit, $(k)$ business development, $(l)$ new business alternative; and (4) the effectively extension model hat might be able to empower the $S C$ is the extension that became their own program and applies (a) a digging finding, and developing science and technology model, (b) interactive/convergent communication, (c) extension substances based on SC need, (d) adult learning process, and (e) community based forest management.
\end{abstract}

Keywords: extension autonomous, empowerment shifting cultivator, cultivator needs, indigenous knowledge.

\section{Pendahuluan}

Pemberdayaan Peladang Berpindah (PB) memusatkan perhatian pada empat isu pokok, yaitu: isu profesionalisme penyuluhan, (2) isu kebutuhan PB, (3) isu pemberdayaan, dan (4) isu pengelolaan hutan lestari. Salah satu penyebab kurang/tidak efektifnya penyuluhan adalah adanya anggapan bahwa penyuluhan dapat dilakukan oleh siapa saja. Adanya anggapan, penyuluhan yang dilakukan oleh seorang penyuluh profesional (isu pertama) dengan tidak profesional akan sama hasilnya, bahkan ada kalangan yang beranggapan bahwa penyuluhan pembangunan tidak perlu dilakukan (Hubies et al., 1994). Dahama dan Bhatnagar (1981) menyatakan bahwa penyuluhan akan efektif bila berorientasi pada kebutuhan sasaran (isu kedua). Slamet (1994) menyatakan bahwa sebagian besar penyuluhan yang dilakukan selama ini belum sepenuhnya mampu 
memenuhi kebutuhan sasaran penyuluhan. Kegiatan penyuluhan sering dimanfaatkan untuk kepentingan poltik dan ekonomi yang berkuasa, sehingga kurang dirasakan manfaatnya dari sisi sasaran penyuluhan (Sumarjo, 2000). Penyuluhan belum mampu meningkatkan keberdayaan (isu ketiga) atau kemandirian, malahan justru meningkatkan ketergantungan.

Pengelolaan hutan lestari (isu keempat) selama ini cenderung top down dan mengabaikan kepentingan komnitas lokal (indigeneous community) yang tinggal di kawasan hutan (Sunderlin dan Ida, 1997). Suara mereka tidak terwakili (voicelessness dan powerlessness) dalam proses pengambilan keputusan padahal keputusan yang dihasilkan sangat mempengaruhi kehidupan/kesejahteraan mereka. Aksesibilitas komunitas lokal semakin berkungan pada sumberdaya hutan padahal meeka mempunyai kearifan lokal dan sistem kepercayaan yang potensial mengelola hutan secara lestari.

\section{Permasalahan Penelitian}

Faktor-faktor apa saja yang mempengaruhi: (1) tingkat keberdayaan PB?, (2) kualitas penyuluhan memberdayakan PB?,
(3) tingkat pemenuhan kebutuhan PB?, (4) kualitas pengelolaan perladangan?, dan (5) bagaimana model penyuluhan yang tepat dan efektif bagi upaya pemberdayaan PB?

\section{Tujuan Peelitian}

Mengkaji faktor-faktor determinan yang mempengaruhi (1) tingkat keberdayaan $\mathrm{PB}$, (2) peningkatan kualitas penyuluhan memberdayakan $\mathrm{PB}$, (3) tingkat pemenuhan kebutuhan PB, (4) kualitas pengelolaan perladangan, dan (5) merumuskan model penyuluhan yang tepat dan efektif memberdayakan PB.

\section{Metode Penelitian}

Penelitian merupakan penelitian survei. Alat pengumpulan data yang utama adalah kuesioner dan didukung oleh wawancara mendalam dan diskusi kelompok terarah. Penelitian ini dilakukan di tiga kabupaten, enam kecamatan dan 12 Desa. Responden terdiri atas 36 penyuluh dan 288 PB. Lokasi penelitian dipilih secara acak sederhana berdasarkan wilayah tuas penyuluh dan persabaran responden PB. Data dianalisis dengan teknik analisis deskriftif melalui bantuan Chi Square, Rank Spearman, dan Analisis Jalur. Penelitian dilakukan sejak Nipember 2002 s/d Maret 2004. 


\section{Hasil dan Pembahasan}

$\underline{\text { Pola Perladangan Berpindah }}$

Pada Gambar 1: mulai-mula peladang menggunakan Ladang 1 selama 1-2 tahun, kemudian mereka pindah ke Ladang 2, dari Ladang 3, dan seterusnya sampai ke Ladang 6. Akan tetapi, peladang kembali lagi ke Ladang 1 setelah masa bera 4-6 tahun.

Ladang bisanya ditanami padi. Disamping tanaman padi, sebagian peladang menanam palawija dan sayur-mayuran. Apabila dang yang sedang diusahakan tidak subur lagi, maka mereka pindah ke ladang lain. Ladang yang ditingkalkan bisanya ditanami dengan tanaman keras seperti karet, kemiri, durian, mangga, dan rotan. Tujuan menanam tanaman keras memiliki tiga fungsi, yaitu: (1) sebagai pertanda bahwa ladang tersebut ada pemiliknya, (2) sebagai sumber penghasilan/jaminan hari tua, dan (3) sebagai sarana memelihara kesuburan lahan.
Kondisi hutan dikawasan perladangan sangat berpengaruh terhadap pola perladangan. Pada saat hutan primer masih luas, peladang masih dapat memperluas lahan dan hutan merupakan sumber penghasilan yang penting. Sumber penghasilan dari hasil hutan non-kayu (HHNK) adalah rotan, gaharu, damar, dan madu.

Faktor-faktor Determinan yang

Mempengaruhi Tingkat Keberdayaan PB

Pada Gambar 2 terlihat bahwa kualitas penyuluhan memberdayakan PB yang tinggi akan berpengaruh terhadap tingkat keberdayaan $\mathrm{PB}$, dibanding pengaruhnya secara langsung, apabila didukung oleh kualitas sumberdaya PB yang tinggi dan kekuatan motivasi PB yang tinggi. Kontribusi pengaruh langsung kualitas penyuluhan memberdayakan PB (Y) adalah sebesar 34,6\% dan kontribusi pengaruh tidak langsung

Gambar 2, Model Hubungan antar Faktor-Faktor yang Mempengaruhi Tingkat Keberdayaan PB 
adalah sebesar $65,4 \%$ terhadap tingkat keberdayaan PB (Y2). Upaya peningkatan keberdayaan PB jauh lebih bila didukung oleh kualitas sumberdaya pribadi, kekuatan motivasi, dan tingkat keberdayaan PB dari pada hanya meningkakan kualitas penyuluha memberdayakan PB.

\section{Faktor-Faktor Determinan yang}

Mempengaruhi Kualitas Penyuluhan

Memberdayakan PB

Pada Gambar 3 terlihat bahwa kualitas sumberdaya pribadi yang tinggi akan berpengaruh makin tinggi terhadap kualitas penyuluhan memberdayakan, dibanding pengaruhnya secara langsung, apabila didukung oleh kualitas sikap profesionalisme kualitas peuluhan memberdayakan, dibading pengaruhnya secara langsung, apabila didukung oleh kekuatan motivasi penyuluh yang tinggi dan iklim organisasi penyuluhan yang baik. Kompetensi penyuluh yang tinggi akan berpengaruh makin tinggi terhadap kualitas penyuluh memberdayakan, dibanding pengaruhnya secara langsung, apabila didukung oleh kualitas sikap profesionalisme penyuluh yang tinggi dan kekuatan motivasi penyuluh yang tinggi. Iklim organisasi penyuluhan yang baik akan berpengaruh makin baik terhadap kualitas penyuluhan memberdayakan,dibanding pengaruhnya secara langsung, apaila didukung oleh kekuatan motivasi penyuluh yang tinggi.

Gambar 3. Model hubungan antar faktor-faktor ang mempengaruhi peningkatan kualtias penyuluhan memberdayakan PB

penyuluh yang tinggi, kompetensi penyuluh yang tinggi, kekuatan motivasi penyuluh yang tinggi, dan iklim organisasi penyuluhan yang kondusif bagi pelaksanaan penyuluhan. Kualitas sikap profesionalisme penyuluh yang tinggi akan berpengaruh makin tinggi tehadap
Faktor-faktor Determinan yang Mempengaruhi Tingkat Pemenuhan $\underline{\text { Kebutuhan PB }}$

Pada Gambar 4 terlihat bahwa kualitas sumberdaya pribadi PB yang tinggi akan berpengaruh makin tinggi terhadap tingakt 
Gambar 4. Model hubungan antar faktor-faktor yang mempengaruhi pemeuhan kebutuhan PB

pemenuhan kebutuhan $\mathrm{PB}$, dibanding pengaruhnya secara langsung, apabila didukung oleh kekuatan motivasi PB yang tinggi.

Kontribusi pengaruh langsung kualitas sumberdaya prbadi PB (X6) adalah sebesar $77 \%$ dan kontribusi pengaruh tidak langsung adalah sebesar $23 \%$ terhadap tingkat pemenuhan kebutuhan PB (X8). Kualitas pendukung keberdayaan $\mathrm{PB}$ yang tinggi akan berpengaruh makin tinggi terhadap tingkat pemenuhan kebutuhan PB dibanding pengaruhnya secara langsung, apabila didukung oleh kekuatan motivasi PB yang tinggi. Kontribusi penaruh langsung kualitas pendukung keberdayaan PB (X9) adalah sebesar 68,6\% dan konribusi penaruh tidak langsung adalah sebesar $31,4 \%$ terhadap tingkat pemenuha kebutuhan PB (X8).
Faktor-faktor Determinan yang Mempengaruhi Kualitas Pengelolaan Perdagangan

Pada Gambar 5 dapat dilihat bahwa masing-masing pebah yaitu: (1) kualitas sumberdaya pribadi PB yang tinggi, (2) kekuatan motivasi PB yang tinggi, (3) tinkat pemenuhan kebutuhan PB yang tinggi, (4) kualitas pendukung keberdayaan pb yang baik, dan (5) kualitas lingkungan eksternal yang baik, akan berpengaruh makin tinggi terhadap kualitas pengelolaan perladangan, dibanding pengaruhnya secara langsung, apabila didukung oleh tingkat keberdayaan PB yang tinggi. Hal ini berarti bahwa keberdayaan PB merupakan faktor kunci bagi peningkatan kualitas pengelolaan perladangan. 


\section{Model Pemberdayaan PB}

Hasil penelitian menunjukkan bahwa PB memiliki keberdayaan yang rendah (low power) terutama disebabkan (1) kualitas sumberdaya manusianya yang rendah, (2) kebutuhan yang kurang terpenuhi, (3) kondisi eksternal yang kurang baik, (4) kemampuan PB menggunakan kelembagaan sosial, ekonomi, adat, dan politik yang rendah (5) infrastruktur yang kurang memadai, dan (6) kualitas penyuluhan memberdayakan $\mathrm{PB}$ yang kurang baii. Kualitas sumberdaya pribadi PB yang rendah dilihat dari (a) status sosial ekonomi, dan (b) kekosmopolitan. Status sosial ekonomi yag buruk tergambar dari (i) jumlah tahun pendidikan yang rendah $(35,6 \%$ tidak pernah sekolah), (ii) $5 \%$ pernah ikut pelatihan, (iii) $90 \%$ tidak mampu tulis baca dan (iv) pendapatan rata-rata Rp 460.000 per bulan. Kekosmopolitan yang buruk tergambar dari (i) intensitas perjalanan ke luar desa saru kali/bulan, (ii) pertemuan dengan penyuluh selama 3 bulan sekali, (iii) pertemuan dengan pejabat luar desa sekali 6 bulan, dan (iv) sumber informasi $(15 \%$ tv/radio, $2 \%$ surat kabar, $1 \%$ majalah, dan $80 \%$ tidak pernah menggunakan).

Kebutuhan yang kurang terpenuhi dengan nilai rata-rata sebesar 39,8(pada skala 0-100) meliputi semua jenis kebutuhan PB, yakni: (a) peningkatan pendapatan, (b) peningkatan produksi, (c) pengembangan usaha, (d) permodalan, (e) alternatif usaha, (d) pemasaran, (e) hubungan dengan pihak ketiga, (f) kebutuhan penyuluhan, dan (g) kebutuhan indentitas. Kondisi eksternal tergambar dari buruknya (a) penerapan kebijakan pembangunan pertanian dan kehutanan (b) desakan penggunaan kawasan perladangan dan (c) penerapan kebijakan pembinaan PB.

Infrastruktur yang kurang memadai tergambar dari kondisi sarana jalan dan

Gambar 5. Model Hubungan antar faktor-faktor yang mempengaruhi kualitas pengelolaan perladangan 
transportasi yang memprihatinkan akibatnya beberapa desa masih relatif terisolasi. Pengelolaan perladangan kondisi kurang baik dan egaliter. PB sehingga proses pemberdayaan berlangsung secaa demokratis dan egaliter. PB sebagai sumber informasi

Gambar 6. Model Pemberdayaan PB

tergambar dari (a) aspek kognitif tentang ciri biofisik hutan lestari sebesar 41; (b) aspek afektif tenang bifisik hutan lestari sebesar 63,9; (c) aspek psikomotorik tentang biofisik hutan lestari sebesar 47,5; (d) aspek kognitif tentang nilai-nilai kepercayaan sebesar 39; (e) aspek afektif tentang nilai-nilai kepercayaan sebesar 67,7; dan(f) aspek psikomotor tentang nilai-nilai kepercayaan sebesar 43,3.

Pada Gambar 6: tahap pertama, identifikasi kebutuhan PB dilakukan bersama oleh penyuluh kompeten dengan PB. Pada tahap ini sudah dipetakan kondisi kebutuhan PB, sumberdaya pribadi PB dan motivasi PB. Pada tahap kedua, melalui dukungan organisasi penyuluhan yang otonom, penyuluh kompeten berfungsi sebagai fasilitator mediator dan pemandu proses pembelajaran $\mathrm{PB}$ sehingga proses pemberdayaan berlangsung secaa demokratis dan berkedudukan sebagai subyek banyak terlibat dalam proes menemukan, menggali, dan mengembangkan IPTEK. Pada tahap ketiga akan terjadi peningkatan keberdayaan PB meliputi aspek kognitif, afektif, dan psikomotor, secara proporsional. Keberdayaan PB akan menghasilkan kemampuan pengelolaan perladangan yang bai, ditandai (a) pendapatan meningkat, (b) kualitas hidup meningkat, dan (c) lingkungan perladangan makin kondusif, dan pengelolaan hutan berbasis komunitas. Keberhasilan program tergantung pada $\mathrm{PB}$, apabila $\mathrm{PB}$ menilai hasilnya belum memuaskan maka $\mathrm{PB}$ dapat memberikan umpan balik bagi penyempurnaan program pemberdayaan. Pada tahap keempat, merupakan tujuan jangka panjang, akan tercipta (a) masyarakat sejahtera, (b) kearifan lokal membudaya, dan (c) biofisik terpelihara. 


\section{Kesimpulan}

(1) Faktor determinan peningkatan keberdayaan PB adalah: (a) kualitas sumberdaya pribadi $\mathrm{PB}$, (b) kekuatan motivasi $\mathrm{PB}$, (c) tingkat pemenuhan kebutuhan PB, (d) kualitas pendukung keberdayaan $\mathrm{PB}$, (c) kualtias lingkungan eksternal PB, dan (f) kualitas penyuluhan memberdayakan PB.

(2) Faktor determinan peningkatan kualitas penyuluhan memberdayakan adalah: (a) kualitas sumberdaya pribadi penyuluh, (b) kualitas sikap profesionalisme penyuluh, (c) iklim organisasi penyuluhan, (d) kekuatan motivasi penyuluh, dan (e) kompetensi penyuluh.

(3) Faktor determinan peningkatan pemenuhan kebutuhan PB adalah: (a) kualitas sumberdaya pribadi $\mathrm{PB}$, (b) kekuatan motivasi PB, (c) kualitas pendukung keberdayaan $\mathrm{PB}$, dan (d) kualias lingkungan eksternal PB.

(4) Faktor determinan peningkatan kualitas pengelolaan perladangan adalah: (a) kualitas sumberdaya pribadi $\mathrm{PB}$, (b) kekuatan motivasi $\mathrm{PB}$, (c) tingkat pemenhan kebutuhan $\mathrm{PB}$, (d) kualitas pendukung keberdayaan $\mathrm{PB}$, (e) kualitas lingkungan eksernal $\mathrm{PB}$, dan (f) tingkat keberdayaan PB.

(5) PB mengalami kekurangberdayaan antara lain terlihat dari (a) pendidikan dan jumlah penghasilan yang rendah, (b) dedakan penggunaan lahan perladangan dari perusahaan dan ketiadaan HHNK, (c) tidak adanya alternatif usaha baru, (d) kebutuhan yang diperlukan berkaitan dengan usaha perladangan yang kurang terpenuhi, (e) kemampuan PB menggunakan kelembagaan sosial, ekonomi, adat, dan politik yang rendah, (f) infrastruktur yang buruk, dan (g) penyuluhan yang sudah dilaksanakan masih buruk.

(6) Model penyuluhan yang efektif memberdayakan PB adalah penyuluhan merupakan program $\mathrm{PB}$ yang menerapkan (a) model menggali, menemukan, dan mengembangkan IPTEK, (d) komunikasi interaktif/konvergen, (c) substansi penyuluhan berbasis kebutuhan $\mathrm{PB}$, (d) proses belajar orang dewasa, dan (e) pengelolaan hutan berbasis komunitas.

(7) Pemberdayaan PB akan mencapai hasil optimal apabila didukung oleh (a) penyuluh kehutanan profesional, (b) organisasi pelaksana penyuluhan yang otonom, (c) komitmen pemerintah terhadap pengembangan kualitas penyuluhan, dan (d) pengembangan teknologi tepat guna.

\section{Rujukan}

Dhama, O.P., dan O.P. Bhatnagar. 1980. Education and Communication for Development. New Delhi: Oxford \& IBH Publishing Co.

Hubies, Aida V.S., Prabowo Tjitropranoto, dan Wahyudi Ruwiyanto. 1994. Penyuluhan Pembangunan di Indonesia: Menyongsong Abad XXI. Jakarta: Ditjen Peternakan, Deptan.

Slamet, Margono, dan P.S. Asngari. 1969. Penyuluhan Peternakan. Jakarta: Ditjen Peternakan, Deptan.

Sumarjo. 2000. Pemberdayaan Masyarakat Melalui Penyuluhan. Makalah disampaikan dalam Acara Penyegaran Peyuluhan Swadaya Tahun 2000. Pusat Bina Penyuluhan Kehutanan dan Perkebunan, Jakarta 21 Nopember 2000.

Sunderlin, William D., dan Ida Aju Pradnya Resosudarmo. 1997. Laju dan Penyebab Deforestasi di Indonesia: Penelaahan Kerancuan dan Penyelesaiannya. (http://www.cifor.cgir.org/publications/p df_files/OccPpaers/OP-091.pdf). (1803-2002). 